\title{
THE EFFECTS OF BACKPACKS OF DIFFERENT STRUCTURES WITH DIFFERENT LOADS ON SHOULDER TO BACK PRESSURE IN PRIMARY SCHOOL STUDENTS
}

\author{
Nan ZHOU ${ }^{1,2}$, Wuyong $\mathrm{CHEN}^{1 *}$, Jin ZHOU ${ }^{1}$, Luming YANG ${ }^{1}$, Xiaoyan ZHANG \\ ${ }^{1}$ National Engineering Laboratory for Clean Technology of Leather Manufacture, Sichuan University, Chengdu 610065, China \\ ${ }^{2}$ Guangzhou Shiling Leather \& Leather Products Investigation Center Co. Ltd, Guangzhou, 510850, China \\ Received: 27.09.2016 Accepted: 20.12.2016 https://doi.org/10.24264/lfj.17.1.1 \\ THE EFFECTS OF BACKPACKS OF DIFFERENT STRUCTURES WITH DIFFERENT LOADS ON SHOULDER TO BACK PRESSURE IN PRIMARY \\ SCHOOL STUDENTS \\ ABSTRACT. The main purpose of this study was to evaluate the difference between soft and hard backpacks in pressure transmission effect \\ and decompression with increased load weight. mFLEX was used to measure shoulder to back pressure on 100 primary school students (male- \\ female ratio $4: 6$ ) wearing different bag loads (equivalent to $5 \%, 10 \%, 15 \%, 20 \%$ and $25 \%$ of their body weights). Meanwhile, a comparative \\ analysis test was done between backpacks of different structures (red backpack A with shoulder and back cushion design and regular yellow \\ backpack B without shoulder and back cushion design). The conclusion is, along with the increase of backpack load, shoulder to back pressure \\ value increased significantly, among them shoulder pressure value increased linearly, and back pressure value increased exponentially. \\ Pressure values of the cushion bag $(A)$ in three areas were all significantly larger than those of control bag (B). The results of the study are \\ contrary to our hypothesis. Instead of effectively alleviating the concentration of pressure in three stress areas, left shoulder, right shoulder \\ and lower back (LS, RS and LB), the buffer structure increases the pressure values. Therefore, in main pressure areas, we cannot simply rely \\ on adding buffer structure to reduce the pressure generated by loading.
}

KEY WORDS: backpack, load, structure, shoulder-back pressure, primary school students

\section{INFLUENȚA RUCSACURILOR CU DIFERITE STRUCTURI ȘI SARCINI ASUPRA PRESIUNII ÎN ZONA UMERILOR ȘI A SPATELUI LA ELEVII DE} SCOALĂ PRIMARĂ

REZUMAT. Scopul principal al acestui studiu a fost acela de a evalua diferența dintre rucsacurile moi și dure în ceea ce privește transmiterea presiunii și decomprimarea odată cu creșterea greutății. S-a utilizat sistemul mFLEX pentru a măsura presiunea în zona umeri-spate la 100 de elevi de școală primară (raportul băieți:fete de 4:6) purtând rucsacuri cu diferite sarcini (echivalente cu 5\%, 10\%, 15\%, 20\% și 25\% din greutățile corporale ale acestora). În același timp, s-a efectuat o analiză comparativă între rucsacurile cu diferite structuri (rucsacul roșu A cu pernuțe în zona umerilor și a spatelui și rucsacul B obișnuit, de culoare galbenă, fără pernuțe în aceste zone). Concluzia este că, odată cu creșterea greutății rucsacului, valoarea presiunii în zona umeri-spate a crescut în mod semnificativ; valoarea presiunii în zona umerilor a crescut liniar, iar valoarea presiunii în zona spatelui a crescut exponențial. Valorile presiunii în cazul rucsacului cu pernuțe (A) în trei regiuni au fost în mod semnificativ mai mari decât cele obținute în cazul rucsacului de referință (B). Rezultatele studiului sunt contrare ipotezei noastre. În loc să atenueze în mod eficient presiunea concentrată în trei regiuni importante - umărul stâng, umărul drept și zona lombară (LS, RS și LB), structura tampon duce la creșterea valorilor presiunii. Prin urmare, în regiunile principale de presiune nu ne putem baza pe adăugarea unei structuri tampon pentru a reduce presiunea generată de greutate.

CUVINTE CHEIE: rucsac, sarcină, structură, presiune umăr-spate, elevi de școală primară

LES EFFETS DES SACS À DOS AUX STRUCTURES ET CHARGES DIFFÉRENTES SUR LA PRESSION À L’ÉPAULE ET AU DOS CHEZ LES ÉLÈVES DE L'ÉCOLE PRIMAIRE

RÉSUMÉ. Le but principal de cette étude a été d'évaluer la différence entre les sacs à dos souples et durs en ce qui concerne l'effet de transmission de la pression et la décompression avec le gain de poids. On a utilisé le système mFLEX pour mesurer la pression dans la région des épaules et du dos chez 100 élèves de l'enseignement primaire (rapport garçons-filles de 4:6) portant des sacs à dos aux charges différentes (équivalant à $5 \%, 10 \%, 15 \%, 20 \%$ et $25 \%$ de leur poids corporel). Dans le même temps, On a effectué une analyse comparative entre des sacs à dos aux différentes structures (un sac à dos rouge $\mathrm{A}$ avec des coussins dans les régions des épaules et du dos et un sac à dos jaune régulier B sans coussin dans les régions des épaules et du dos). La conclusion est que, avec l'augmentation de la charge du sac à dos, la pression dans les régions des épaules et du dos a augmenté de façon significative; la pression sur les épaules a augmenté linéairement, et la pression sur le dos a augmenté exponentiellement. Les valeurs de pression du sac à coussin $(A)$ dans trois régions ont été significativement plus grandes que celles du sac de référence (B). Les résultats de l'étude sont contraires à notre hypothèse. Au lieu d'atténuer efficacement la concentration de pression dans trois régions importantes, l'épaule gauche, l'épaule droite et la région lombaire (LS, RS et LB), la structure tampon augmente les valeurs de pression. Par conséquent, dans les régions principales de pression, nous ne pouvons pas simplement compter sur l'ajout d'une structure tampon pour réduire la pression générée par la charge.

MOTS-CLÉS: sac à dos, charge, structure, pression sur les épaules et sur le dos, élèves de l'enseignement primaire

\section{INTRODUCTION}

The backpack issue has aroused attention from all sectors of society. Unreasonable structure design of backpacks and overload might cause students vertebral, shoulder and back and musculoskeletal pain, and therefore impact the growth and development of students directly or indirectly $[1,2]$. Investigation shows that back pain is very common among primary school students [3].
Among the current research studies, scholars have started to consider health problems caused by the process of carrying backpacks and have analyzed the impact of bag weight and the way of wearing it on the bodies of primary school students, including plantar pressure, angle of inclination of the body, muscle tone, etc. Based on test results, some papers suggested that the load of the backpack should be no more than $10 \%$ of human body weight [4], or $15 \%$ as critical

* Correspondence to: Wuyong CHEN, National Engineering Laboratory for Clean Technology of Leather Manufacture, Sichuan University, Chengdu 610065, China, email: wuyong.chen@163.com 
safety value [5]. School bags with symmetrical design should be selected [6]. But there are few research studies on the impact of backpacks of different design structures on human biomechanical properties during walking. Marsh et al. [7] analyzed the impact of backpacks on posture in adolescents wearing backpacks with and without abdominal supports, Mackie et al. [8] used questionnaires to compare four different school backpacks from perspectives such as appearance and function; Ramadan et al. [9] modified a backpack design for male school children, and compared the effect of modification on parameters such as muscle tone and heartbeat. Reports on the effect of different bag structures on shoulder to back pressure value have not been found yet. But few have paid attention to the impact of bags on human shoulder to back pressure. A few papers have paid attention to the reason for shoulder to back pain in certain groups of people doing special jobs, such as pilots, and mechanic troops [10, $11]$, some researchers have used questionnaires to analyze lower back pain [12], but rarely used instruments to measure quantitatively shoulder to back pressure. Suozzi et al. [13] used a pressure meter to measure shoulder pressure and compare the changes in shoulder pressure, and tests showed that with the increase of angle of inclination, shoulder pressure also increased. Martin and Hooper [14] used Tekscan pressure sensor to measure shoulder pressure, and this method has been adopted by subsequent scholars. Jones and Hooper [15] compared the impact of single- or multiple-layered garments on shoulder pressure when wearing backpacks, and tests showed that the number of layers of garments had no impact on interface pressure. Mackie et al. [16] used a simulative backpack load to measure interface pressure on a model's shoulders, and found out that load had significant impact on shoulder interface pressure. But there has been no paper to analyze the link between changes in shoulder to back pressure value and bag structure, as well as to analyze changes in back pressure value under different loadings. Meanwhile, there is a lack of research supporting how shoulder to back pressure in primary school students changes under the impact of both soft and hard bags with increased load weight.

Therefore, the main aim of the research is to evaluate the difference in pressure transmission effect and decompression between soft and hard bags with increased load weight. Our hypothesis is as follows: compared with hard bags, soft bags with cushion structures on the shoulder and back area have better decompression effect.

\section{METHODS}

\section{Participants}

Altogether 100 healthy children (age: 7-12; grade: 1-6) were recruited. Inclusion criteria were:

1. No foot operation history, no cerebral palsy;

2. Not suffering from scoliosis;

3. No foot injury;

4. Able to walk independently, normal gait.

Prior to the test, the staff communicated thoroughly with the guardians of subjects about the test flow and precautions, and written consents were obtained from them prior to data collection. All tests were approved by the local Ethics Committee, and were conducted according to the Declaration of Helsinki.

\section{Test Bags}

In the test, students wore two types of backpacks, the red backpack with honeycomb cushion structure on both shoulder and back areas (cushion bag (A), see Fig. 1a), and regular yellow backpack without honeycomb cushion structure on shoulder and back areas (control bag (B), see Fig. 1b).

Firstly, the load weight was determined by each subject's body weight. Load weights were $5 \%, 10 \%, 15 \%, 20 \%$ and $25 \%$ of body weight respectively. In the test, subjects wore the school bag starting from $5 \%$ of body weight, increasing the load weight in order until reaching $25 \%$ of body weight.

\section{Test Methods}

The mFLEX pressure measuring system (mFlex, RSscan International, Belgium) was utilized to record the contact pressure between the body and the backpack. In total 24 pressure sensors were used, number 1-6 on the left shoulder, 7-12 on the right shoulder and 13-24 on the lower back. The area of pressure sensors is $0.96 \mathrm{~cm}^{2}$ and the frequency is $5 \mathrm{~Hz}$. Data partition was divided into three areas based on sensors' positions: Left shoulder, Right shoulder and Lower back. Maximum pressure $(\mathrm{mmHg})$ in each area needed to be calculated. 
Prior to each test, strap length and sensor position are adjusted according to each primary school student's body condition. Installation method of mFLEX pressure sensor in the test is shown in Fig. 1. Prior to the test, subjects walked across the test area at a self-preferred speed in natural gait for a 2-3 minute warm-up practice trial wearing the backpack equipped with sensor. Starting from formal collection of pressure data using mFLEX pressure distribution test system, subjects needed to be guided to wear bags of different loads to record pressure distribution on left and right shoulder and back during walking. Effective data of each load group needed to be collected successfully three times, each lasting 10 seconds, each time a total of 50 data points was collected. Interval between various bag loads was $1 \mathrm{~min}$.

\section{Data Processing and Statistical Analysis}

Firstly 50 data points from each test were averaged, then three test data were averaged. All of the data were verified using 1-sample K-S test to check its normal distribution situation. Difference in cushion bag (A) and control bag (B) under different loading conditions was verified by paired samples. All analytical models of the research were performed using SPSS (V20, SPSS Inc., Chicago, USA), significance was defined as 0.05 , confidence interval $95 \%$.

\section{RESULTS}

Of 100 samples in the test, male-female ratio is $4: 6$, mean height $133 \pm 20.5 \mathrm{~cm}$, mean weight $28.6 \pm 14.1 \mathrm{Kg}$. Subjects' basic information is given in Table 1.

First the analysis of the impact of loading on test results, and the result of impact of loading on pressure value was shown in Fig. 2 . With increased load weight, shoulder to back maximum pressure values of both bag $A$ and $B$ increased significantly. Among them, left shoulder maximum pressure value increased linearly along with the increase of load (cushion bag (A) $R^{2}=0.9963$, control bag (B) $R^{2}=0.9909$ ), right shoulder maximum pressure value

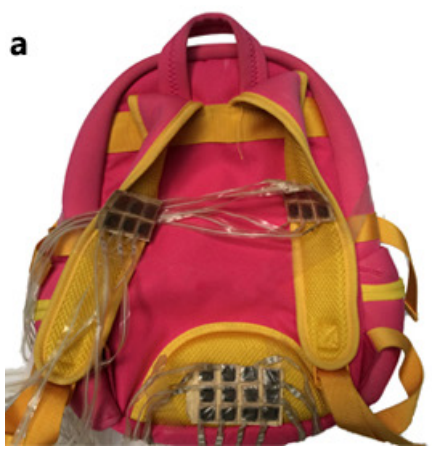

Installation method of cushion bag (A)

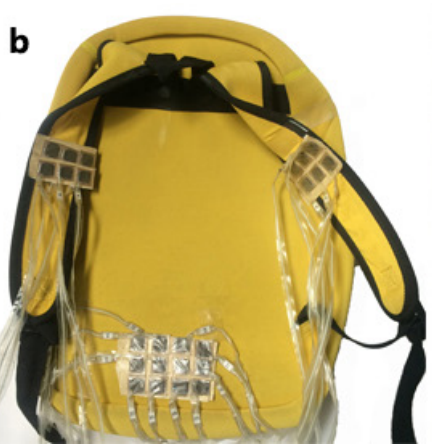

Installation method of control bag (B)

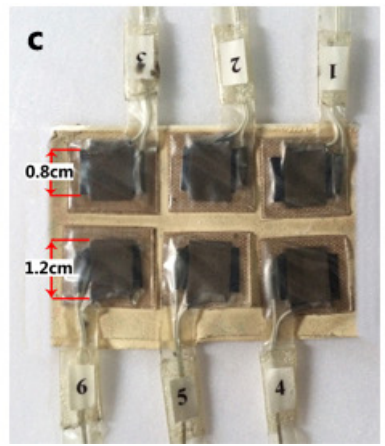

Sensor size

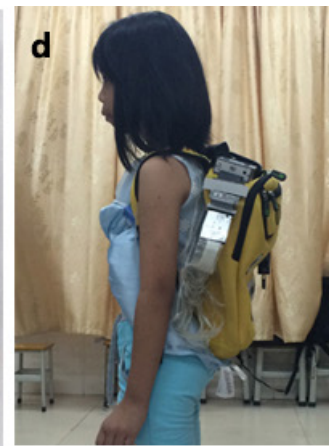

Effect diagram of student with load

Figure 1. Sensors distribution on the bags and test methods

Table 1: Basic information of subjects

\begin{tabular}{ccccccc}
\hline & $7 y r$ & $8 y r$ & $9 y r$ & $10 y r$ & $11 y r$ & $12 y r$ \\
\hline Sample & 14 & 14 & 21 & 26 & 20 & 5 \\
Height/cm & $121 \pm 9$ & $127 \pm 10$ & $131 \pm 11$ & $137 \pm 16$ & $142 \pm 10$ & $145 \pm 6$ \\
Weight/kg & $22.0 \pm 6.4$ & $27.8 \pm 12.6$ & $27.3 \pm 11.2$ & $30.5 \pm 11.4$ & $32.0 \pm 9.7$ & $34.7 \pm 7.6$ \\
BMI & $14.9 \pm 3.6$ & $16.9 \pm 6.3$ & $15.9 \pm 4.1$ & $16.2 \pm 5.3$ & $15.9 \pm 2.8$ & $16.5 \pm 2.7$ \\
\hline
\end{tabular}

Note: BMI, body mass index. 

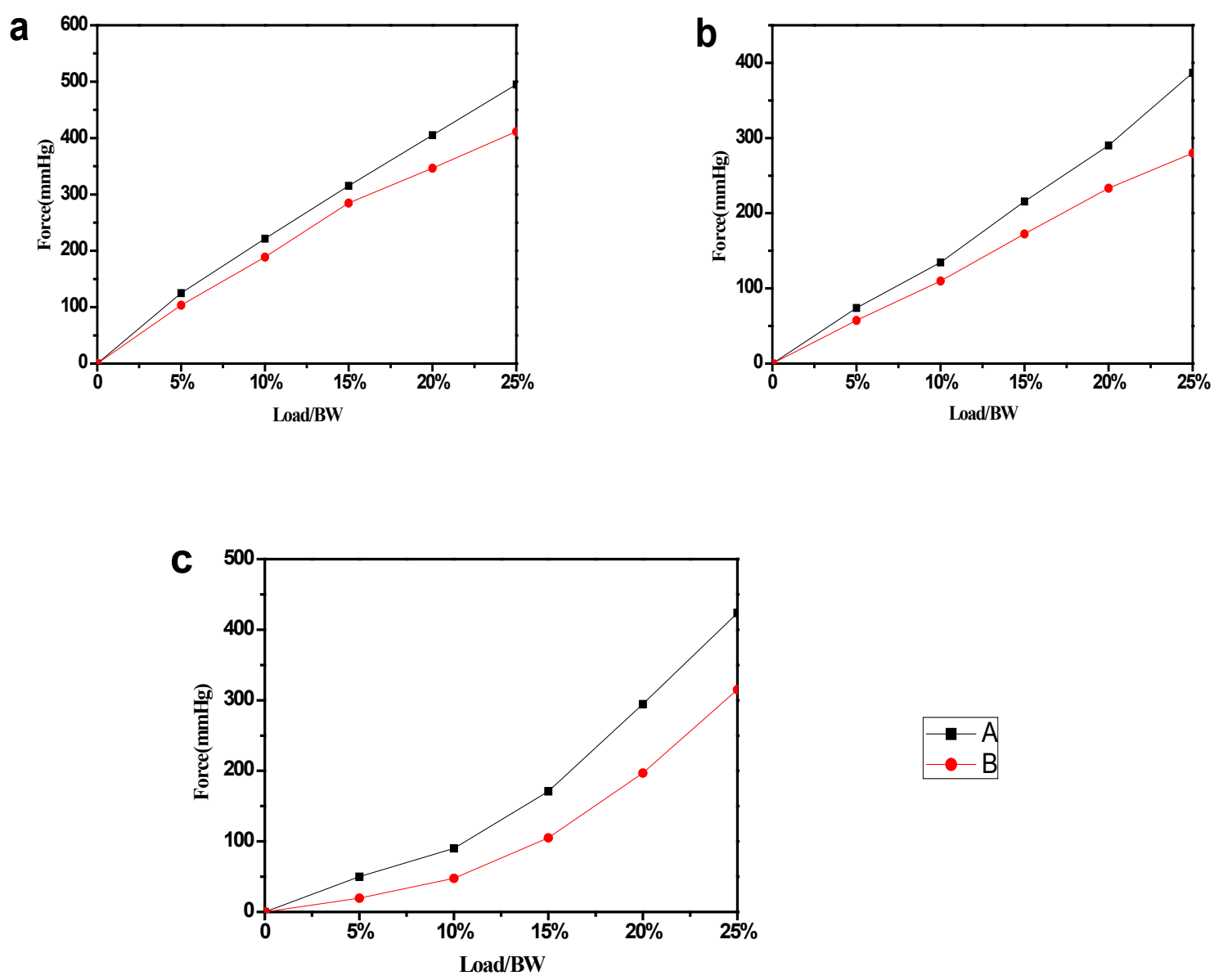

Figure 2. Mean maximum pressure value under various loading conditions of left shoulder (a), right shoulder (b) and back (c)

increased linearly along with the increase of load (cushion bag (A) $R^{2}=0.9956$, control bag (B) $\left.R^{2}=0.9987\right)$, back maximum pressure value increased exponentially along with the increase of load (cushion bag (A) $R^{2}=0.991$, control bag (B) $\left.R^{2}=0.9851\right)$. Under most loading conditions, pressure values of the cushion bag (A) in 3 areas were all significantly larger than those of the control bag (B) (Table 2).

The data in the test does not comply with normal distribution, therefore all analytical models use non-parametric analytical model.

\section{DISCUSSION}

In the test, we did comparative analysis on the changes of pressure in areas LS, RS and LB of the cushion bag $(A)$ and the control bag $(B)$ with increased load weight, and the results showed that pressure values of the cushion bag $(A)$ in three areas were all significantly larger than those of the control bag (B).

The results of this test is contrary to our hypothesis, as well as subverts people's imagination of decompression structure of traditional bags. After analyzing the reasons, we believe that when a backpack is carried, LS, RS and LB form a structure of pressure in 3 areas, at this time a bag without cushion has larger contact surface with the human body, therefore the pressure is not high; but with the adding of decompression materials, e.g. sponge cushion, such as in the case of the cushion bag $(A)$, on one hand this sponge cushion seems to have a buffer effect, in reality it reduces the contact surface of the bag to the body and the human body therefore concentrates the pressure, resulting in higher pressure. Therefore we believe that in backpack design, in the main pressure areas 
Table 2: Difference in two bags under different loadings

\begin{tabular}{|c|c|c|c|c|c|}
\hline \multirow[b]{2}{*}{ Position } & \multirow[b]{2}{*}{ Load } & \multicolumn{4}{|c|}{ Wilcoxon Signed Ranks Test } \\
\hline & & negative rank (B-A) & positive rank (B-A) & Z scores & $p$-values \\
\hline \multirow{5}{*}{ Left shoulder } & $5 \%$ & 44.15 & 40.41 & -1.293 & 0.196 \\
\hline & $10 \%$ & 45.55 & 37.55 & -2.602 & $0.009 *$ \\
\hline & $15 \%$ & 43.60 & 40.88 & -1.762 & 0.078 \\
\hline & $20 \%$ & 49.43 & 34.19 & -3.614 & $0.000 * *$ \\
\hline & $25 \%$ & 54.09 & 28.26 & -4.033 & $0.000 * *$ \\
\hline \multirow{5}{*}{ Right shoulder } & $5 \%$ & 48.15 & 38.97 & -2.472 & $0.013^{*}$ \\
\hline & $10 \%$ & 42.89 & 44.09 & -2.420 & $0.016^{*}$ \\
\hline & $15 \%$ & 44.44 & 35.27 & -3.431 & $0.001 *$ \\
\hline & $20 \%$ & 40.94 & 35.58 & -3.955 & $0.000 * *$ \\
\hline & $25 \%$ & 49.32 & 30.05 & -5.397 & $0.000 * *$ \\
\hline \multirow{5}{*}{ Back } & $5 \%$ & 42.77 & 35.67 & -6.456 & $0.000 * *$ \\
\hline & $10 \%$ & 45.51 & 40.57 & -5.428 & $0.000 * *$ \\
\hline & $15 \%$ & 50.73 & 39.38 & -5.342 & $0.000 * *$ \\
\hline & $20 \%$ & 46.27 & 41.29 & -5.097 & $0.000 * *$ \\
\hline & $25 \%$ & 43.89 & 36.04 & -3.701 & $0.000 * *$ \\
\hline
\end{tabular}

such as LS, RS and LB, we cannot simply rely on adding a buffer structure to alleviate the pressure generated by loading, instead we can alleviate the discomfort of loading by adjusting the center of gravity of the whole bag, increasing waist zone support, etc. Meanwhile, due to the lack of reports on similar tests, appropriate conditions and ranges need to be taken into consideration when comparing with other test results on backpack loading or bag structure design.

\section{CONCLUSIONS}

Instead of effectively alleviating the concentration of pressure in LS, RS and LB, the buffer structure increases the pressure values. Therefore, in the main pressure areas, we cannot simply rely on adding buffer structure to alleviate the pressure generated by loading, instead we can alleviate the discomfort of loading by adjusting the center of gravity of the whole bag, increasing waist area support, etc.

\section{Acknowledgements}

The authors would like to thank those who provided financial support, Science Plan Project (2012, HD12CXY-G0016) of Huadu Area, Guangzhou, Guangdong, and to thank Hecheng Primary School of Shiling Town, Huadu Area, Guangzhou and Guangzhou Nohoo Bag Co., Ltd for their help in experimental data collection.

\section{REFERENCES}

1. Wang, M., Lu, A., Zhang, Q., et al., Research Progress on the Impact of Backpacks on Juveniles' Balance, Body posture and Gait (in Chinese), Tiyu Keyan (Sports Scientific Research), 2015, 36, 2, 8-12.

2. Zhou, N., Chen, W., Yang, L., Zhou, J., Application and Perspective of Biomechanics Analytic Technology in Bag Design (in Chinese), Pige Kexue Yu Gongchen (Leather Science and Engineer), 2015, 25, 5, 27-32.

3. Trevelyan, F.C., Legg, S.J., Back pain in school children-Where to from here?, Appl Ergon, 2006, 37, 45-54.

4. Hong, Y., Brueggemann, G.P., Changes in gait patterns in 10-year-old boys with increasing loads when walking on a treadmill, Gait Posture, 2000, 11, 3, 254-259.

5. Zhou, N., Zhou, J., Yang, L., Chen, W., Investigation of the Effect of Varied Schoolbag Weight on the Health of Primary Students: A Quantitative Plantar Pressure Study, Leather and Footwear Journal, 2015, 15, 3, 159-168.

6. Negrini, S., Negrini, A., Postural effects of symmetrical and asymmetrical loads on the spines of schoolchildren, Scoliosis, 2007, 2, 8, 1-7.

7. Marsh, B., DiPonio, L., Yamakawa, K., et al., Changes in Posture and Perceived Exertion 
in Adolescents Wearing Backpacks with and without Abdominal Supports, Posture, 2006, 509-515.

8. Mackie, H.W., Legg, S.J., et al., Comparison of four different backpacks intended for school use, Appl Ergon, 2003, 34, 257-264.

9. Ramadan, M., Al-Shayea, A.M., A modified backpack design for male school children, Int J Ind Ergonom, 2013, 43, 5, 462-471.

10. Yin, Q., Ye, H., Epidemiological Investigation on Pilot's Neck-shoulder-back Pain during Flight (in Chinese), Zhongguo Liaoyang Yixue (China Rehabilitation Medicine), 2002, 11, 4, 48-50.

11. Xu, Z., Yu, B., Wang, F., et al., Investigation and Analysis on Neck-shoulder-back Pain in Mechanized Troops (in Chinese), Beijing Junqu Yiyao (Beijing Military Region Medicine), 1988, 10, 2, 137-138.

12. Macedo, R.B., Coelho-e-Silva, M.J., et al. Quality of life, school backpack weight, and nonspecific low back pain in children and adolescents, J Pediatr (Rio J), 2015, 91, 3, 263269.
13. Suozzi, B., Brazell, H., O'Sullivan, D., et al., A comparison of shoulder pressure among different patient stabilization techniques, $\mathrm{Am} J$ Obstet Gynecol, 2013, 209, 478.e1-5.

14. Martin, J.L., Hooper, R.H., Military load carriage: A novel method of interface pressure analysis. Proceedings of the RTO HTM Specialist's Meeting on Solider Mobility: Innovations in Load Carriage System Design and Evaluation, Kingston, Canada, 2000.

15. Jones, G.R., Hooper, R.H., The effect of single- or multiple-layered garments on interface pressure measured at the backpack-shoulder interface, Appl Ergon, 2005, 36, 79-83.

16. Mackie, H.W., Stevenson, J.M., Reid, S.A., Legg, S.J., The effect of simulated school load carriage configurations on shoulder strap tension forces and shoulder interface pressure, Appl Ergon, 2005, 36, 199-206.

(C) 2017 by the author(s). Published by INCDTPICPI, Bucharest, RO. This is an open access article distributed under the terms and conditions of the Creative Commons Attribution license (http:// creativecommons.org/licenses/by/4.0/). 